\title{
A facile method for monitoring solid-phase peptide synthesis and for N-terminal modification of peptides: synthesis of short peptides for imaging specific cells
}

\author{
K RAJAVENKATESH, S SANTOSHKUMAR, K PURNASAI and S THENNARASU* (1) \\ Organic and Bioorganic Chemistry Laboratory, CSIR-Central Leather Research Institute, Adyar, Chennai, \\ Tamil Nadu 600 020, India \\ E-mail: thennarasu@gmail.com
}

MS received 2 April 2019; accepted 22 July 2019

\begin{abstract}
A simple method for naked-eye detection of free amine groups during solid-phase peptide synthesis is reported. The technique involves base-catalyzed cyclization of 2-(2-oxo-2H-acenaphthylene-1-ylidene)-malononitrile (1) and subsequent oxidative substitution of aryl moiety by free amine group present at the N-terminus of the peptide chain that leads to the formation of a chromophore, which distinguishes the deprotected peptide chain from the protected one. The reaction is fast, does not require heating, and allows $\mathrm{N}$-terminal modification of peptides suitable for imaging specific cells.
\end{abstract}

Keywords. Chemical modification of peptides; solid-phase peptide synthesis; monitoring agents; peptide labelling; cell imaging.

\section{Introduction}

Solid-phase synthesis of DNA oligomers, organic molecules and peptides have become a user-friendly strategy in targeted and combinatorial syntheses for academic and industrial purposes. As the cost involved in such multistep synthesis of biomolecules is very high, stepwise monitoring is required to ensure completion of reactions at every step. Several qualitative and quantitative methods for monitoring stepwise synthesis in heterogeneous systems have been reported. ${ }^{1-3}$ Two strategies are reported in the literature to monitor the free and protected amine group during solid-phase peptide synthesis: (1) detection of free amine group by color tests before removal of the protecting group ${ }^{4-16}$ and (2) indirect estimation of amine group by determination of the protecting group. ${ }^{17}$ The former strategy is advantageous in the stepwise synthesis of peptides as it allows the detection of free amino group when the coupling is incomplete, prompting the need for a second coupling reaction.

Fluorescent peptides are routinely used for imaging specific cell types and intracellular organelles. Synthesis of peptides labelled with rhodamine, dansyl, and FITC moieties have been reported in the

\footnotetext{
*For correspondence
}

literature. ${ }^{18-20}$ In principle, any $\mathrm{N}$-terminal peptide labelling reaction can be used for monitoring the stepwise synthesis of peptides. Recently, Lenk et al., have reported the synthesis and reactivity of 1-oxo1H-phenalene-2,3-dicarbonitrile (2) with amines and thiols. ${ }^{21}$ While exploring the reactivity of 2-(2-oxo$2 \mathrm{H}$-acenaphthylene-1-ylidene)-malononitrile (1) using organic bases (instead of potassium carbonate reported in the literature), we observed the development of different colors. Therefore, we investigated the utility of $\mathbf{1}$ for monitoring free amine groups during solidphase peptide synthesis. Herein, we report the development of reddish-brown color when $\mathbf{1}$ is treated with deprotected amine group of resin-bound amino acid or peptide. Development of reddish-brown color is also observed when the coupling is incomplete during peptide synthesis. We also present ${ }^{1} \mathrm{H}$ NMR data on N-terminal modification of the peptide chain and the utility of the modified chromogenic peptide in bioimaging.

\section{Materials and methods}

Boc-amino acids, Fmoc amino acids, Rink amide resin $(0.8-1.0 \mathrm{mmol} / \mathrm{g})$, Wang resin $(1.0-1.5 \mathrm{mmol} / \mathrm{g})$, trifluoroacetic acid (TFA), diisopropylethylamine (DIPEA) 2-(1//- 
benzotriazol-1-yl) - 1, 1,3,3-tetramethyluronium hexafluorophosphate (HBTU), hydroxybenzotriazole (HOBT), dicyclohexylycarbodiimide (DCC) and dimethylaminopyridine (DMAP) were obtained from Sigma-Aldrich. A manual peptide synthesizer vessel (Aldrich, USA), was used for peptide synthesis. Synthesis-grade piperidine was procured from Merck (India). Luria-Bertani (LB) broth (12795027) was from Himedia. Staphylococcus aureus (MTCC 3160) was procured from Microbial Type Culture Collection and Gene Bank $(\boldsymbol{M T C})$. The A431 cell lines were obtained from the National Centre for Cell Science (NCCS), Pune, India.

\subsection{Peptide synthesis}

Fmoc chemistry protocol with Rink amide resin and Boc chemistry protocol with Wang resin were used for the synthesis of peptides. ${ }^{2,3}$ For the synthesis of the pentapeptide $\left(\mathrm{NH}_{2}-\mathrm{KNGRG}-\mathrm{CONH}_{2}\right)$ and octapeptide $\left(\mathrm{NH}_{2}-\right.$ KKNGRGDA-CONH$H_{2}$ ), all the amino acids were coupled as HBTU active esters in the presence of an equivalent amount of HOBT. DIPEA was used as the catalyst. At the end of the synthesis, the Fmoc protecting group was removed and the resin was treated with $\mathbf{1}$ for $15 \mathrm{~min}$. Then the resin was washed thoroughly with DMF, DCM, acetic acid and diethyl ether before drying under vacuum. The peptide was cleaved from the resin using a mixture containing TFA, thioanisole, and ethanedithiol $(9.0: 0.5: 0.5, \mathrm{v} / \mathrm{v})$ at room temperature for $2 \mathrm{~h}$ (Scheme 1).

For the synthesis of the tripeptide $\left(\mathrm{NH}_{2}-\mathrm{KRKA}-\mathrm{OH}\right)$, Boc-Lys (Boc)-OH and Fmoc-Alanine-OH were converted into the corresponding symmetric anhydride in DCM and coupled to Wang resin in DMF using DMAP as a catalyst. The other two residues were coupled as HBTU active esters in the presence of an equivalent amount of HOBT using DIPEA as the catalyst. At the end of the synthesis, the Boc protective group was removed using 30\% TFA in DCM. The resin was washed with DCM and DMF, and then treated with 1 for $15 \mathrm{~min}$. Then the resin was washed thoroughly with DMF, DCM, acetic acid and diethyl ether before drying under vacuum. The peptide was cleaved from the resin using a mixture containing TFA, thioanisole, and ethanedithiol (9.0:0.5:0.5, v/v) at room temperature for $3 \mathrm{~h}$ (Scheme 1).

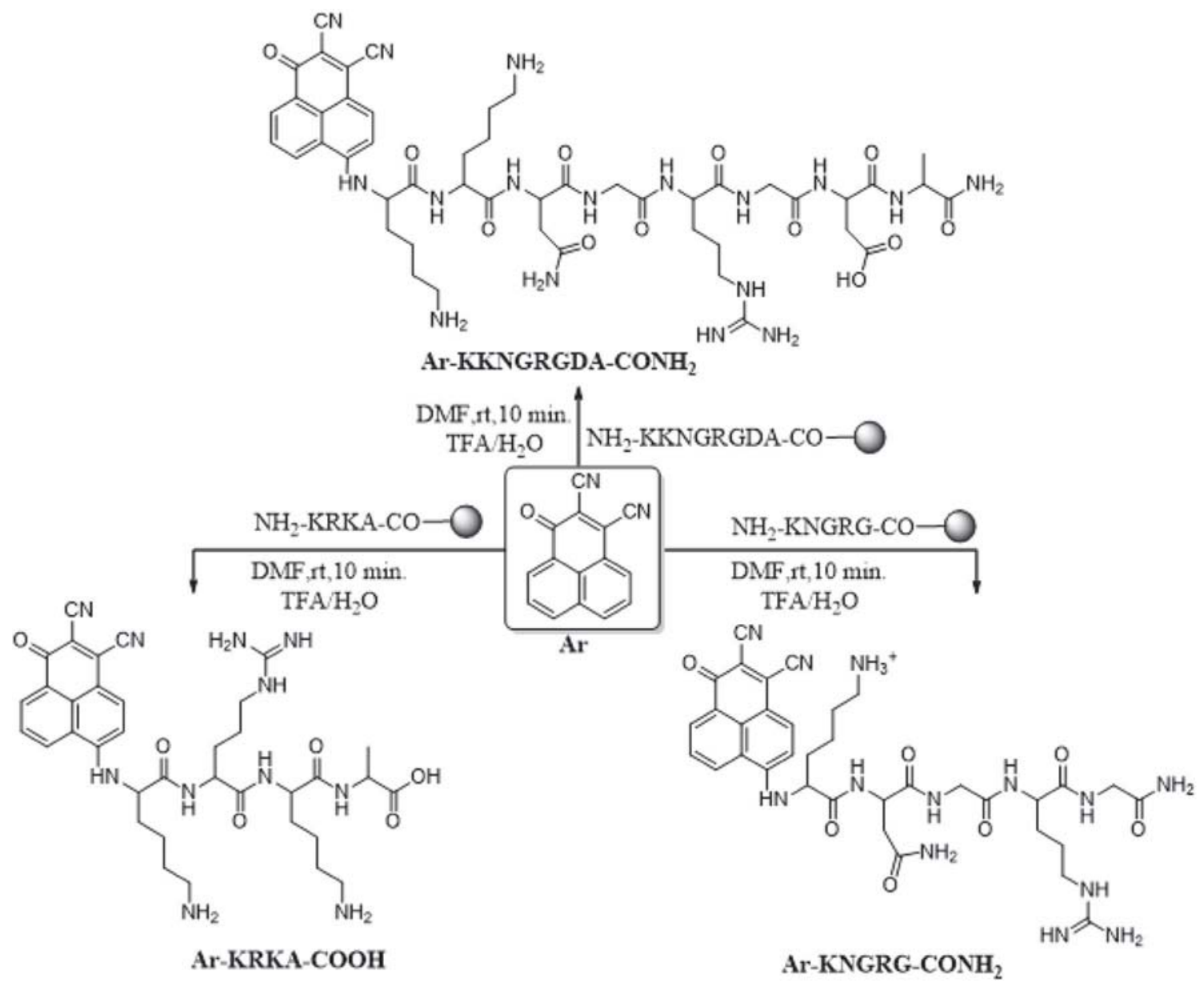

Scheme 1. Synthesis of N-terminal modified peptides 


\subsection{Monitoring peptide synthesis}

For monitoring peptide synthesis, a known quantity $(10 \mathrm{mg})$ of both protected and deprotected peptide-anchored-resin beads were treated with a constant volume $(0.2 \mathrm{~mL})$ of the saturated solution of $\mathbf{2}$ in DMF at room temperature for 5-10 min. After thorough washing, the resin beads appeared pink.

\subsection{Cell imaging}

The A431 cells $\left(5 \times 10^{4}\right.$ cells per $\left.\mathrm{mL}\right)$ along with DMEM medium and other supplements which include penicillin (120 units per $\mathrm{mL})$, streptomycin $(75 \mathrm{mg} / \mathrm{mL})$ and gentamycin $(160 \mathrm{mg} / \mathrm{mL})$, were plated on a 96 well plate and maintained at $37^{\circ} \mathrm{C}$. After $24 \mathrm{~h}$, the culture medium was replaced with a serum-free medium containing peptide solution $(1 \mu \mathrm{M} ; 50 \mu \mathrm{L})$ and incubated at $37{ }^{\circ} \mathrm{C}$ for $4 \mathrm{~h}$ in a humidified atmosphere with $5 \% \mathrm{CO}_{2}$. Then, the plates with scaffold were washed several times with PBS and viewed under a fluorescence microscope.

About $10^{9}$ cells per $\mathrm{mL}$ of Lag phase Staphylococus aureus were suspended in LB broth and allowed to grow overnight. To $1.0 \mathrm{~mL}$ of the subculture, $10 \mu \mathrm{g}$ of peptide was added and incubated for about $30 \mathrm{~min}$. From the test culture, $100 \mu \mathrm{L}$ aliquot was withdrawn and heat-fixed on a glass slide. The fixed cells were visualized under a fluorescent microscope (Leica Microsystems, Germany) using the blue filter.
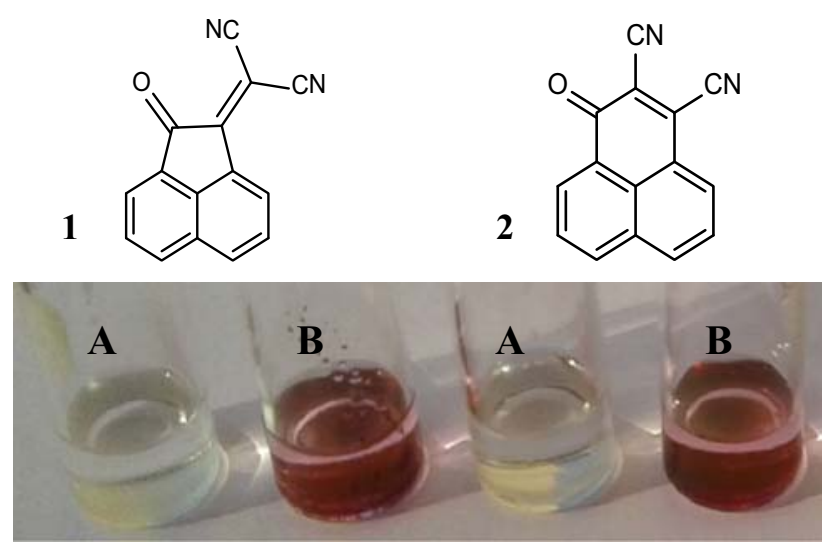

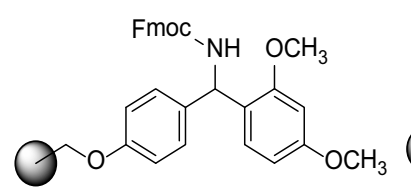

A

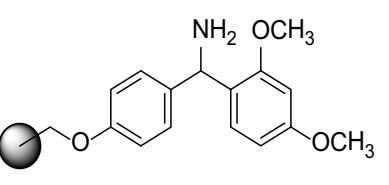

B
Figure 1. Color change when $1(1.0 \mathrm{~mL})$ and $2(1.0 \mathrm{~mL})$ were reacted with protected and deprotected Rink amide resins ( $\mathrm{A}$ and $\mathrm{B}$, respectively). No color change was observed with Fmoc-protected resin (10 mg; A1 and A2). Reddish-brown color was observed with deprotected resin (10 mg; B1 and B2).

\section{Results and Discussion}

Previous studies have established that potassium carbonate catalyzes intramolecular cyclization of $\mathbf{1}$ resulting in the formation of 1-oxo-1H-phenalene-2,3dicarbonitrile (2), which undergoes oxidative substitution with nucleophiles such as amines and thiols. We envisaged that the basic medium adopted in the deprotection step of peptide synthesis would facilitate intramolecular cyclization of $\mathbf{1}$ and subsequent oxidative substitution with the amine group of the peptide chain (Scheme 1). Such a reaction would be useful to monitor solid-phase peptide synthesis and for N-terminal modification of the resin-bound peptide. We first determined the time taken by $\mathbf{1}$ for the development of color upon reaction with a resin-bound amine group. For this purpose, commercially available Fmoc-protected aminomethyl resin (Sigma-Aldrich, Rink amide resin) was deprotected using 20\% piperidine, and then treated with a saturated solution of $\mathbf{1}$ at room temperature for different periods of time. The reaction was so spontaneous that the maximum brown or coffee-brown color developed within $5 \mathrm{~min}$, and treatment for longer periods of time did not improve the color intensity significantly (Figure 1). As expected, similar results were observed with $\mathbf{2}$ as well, and the reddish-brown color remained stable for several days (Figure 1). Thus, both $\mathbf{1}$ and $\mathbf{2}$ could be used to monitor solid-phase peptide synthesis.

When commercially available Fmoc-protected Rink amide resin (10 mg, 50-90 mesh, Sigma-Aldrich) was treated separately with $0.2 \mathrm{~mL}$ of stock solutions 1 for $10 \mathrm{~min}$, no characteristic change in the color of the resin was observed. However, reddish-brown color

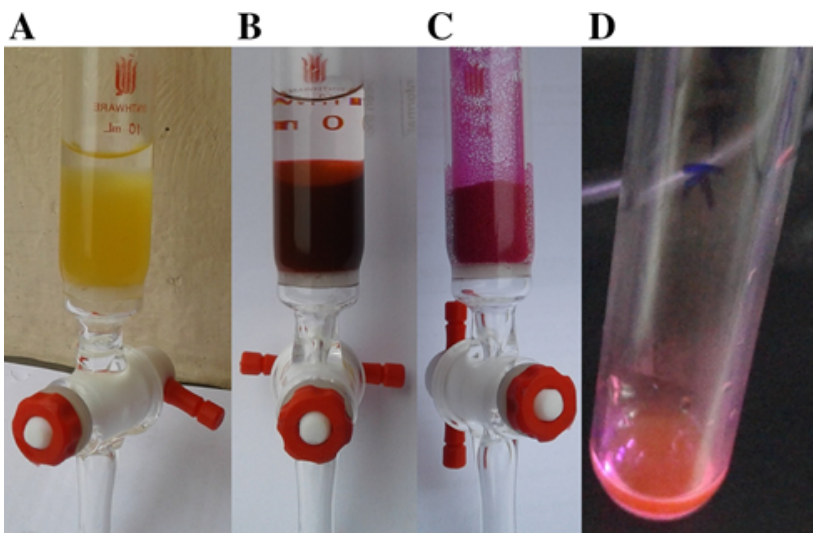

Figure 2. N-terminal labeling of octapeptide: (A) peptidebound resin in DMF after removal of Fmoc-protective group, (B) N-terminal labeled peptide-bound resin in DMF, (C) N-terminal labeled peptide-bound resin (after removal of solvents), and (D) HPLC fraction collected at $\sim 17.9$ min (the pink color is due to $\mathrm{N}$-terminal labelling of peptide). 

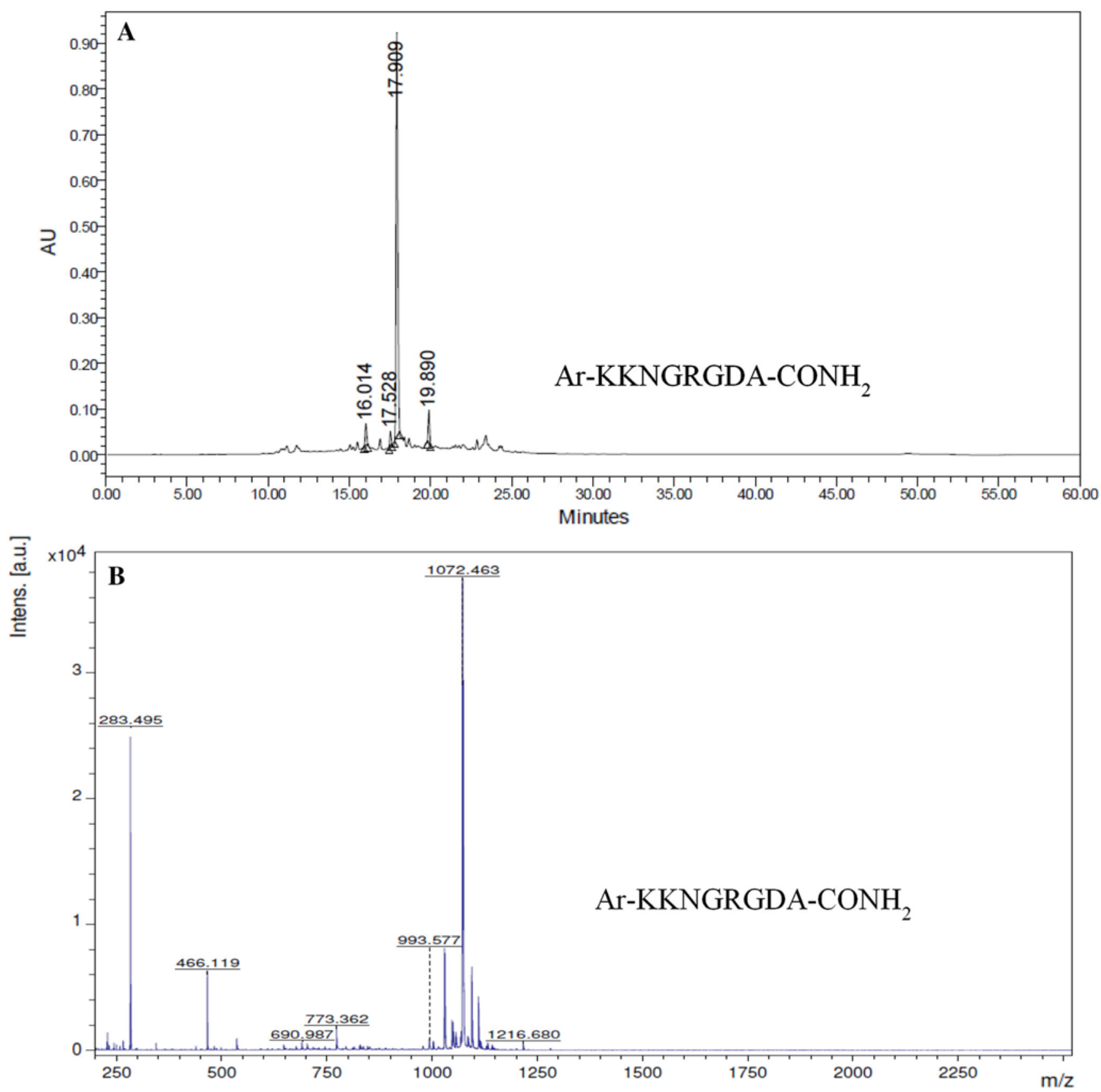

Figure 3. N-terminal modification of octapeptide: (A) HPLC profile and (B) ESI-MS profile of crude octapeptide after $\mathrm{N}$-terminal modification. The calculated mass of the peptide is 1071.93 .

development was observed on the resin after removal of the Fmoc-protective group. Then, alanine was anchored as the first amino acid to the resin and the protective group was removed using standard Fmocchemistry protocols. Both protected and free forms of resin-bound-alanine were treated separately with 0.2 $\mathrm{mL}$ of the stock solutions of $\mathbf{1}$. The development of reddish-brown color was observed only in the resin containing free alanine. The reddish-brown color was not observed on resin beads when the amine group of alanine was protected. Thus, the development of reddish-brown color permitted naked-eye detection of protected and deprotected forms of resin-bound amino acid and confirmed the utility of $\mathbf{1}$ in monitoring peptide synthesis.

We, then, set out to synthesize an octapeptide $\left(\mathrm{NH}_{2}^{-}\right.$ KKNGRGDA-CONH ${ }_{2}$ ) which encompasses RGD and NGR sequences, which show high affinity for the integrins, a family of membrane proteins over-expressed in cancer cells. Hence, the N-terminal modified octapeptide (Ar-KKNGRGDA-CONH${ }_{2}$ ) can be expected to bind cancer cells selectively, and thereby, 

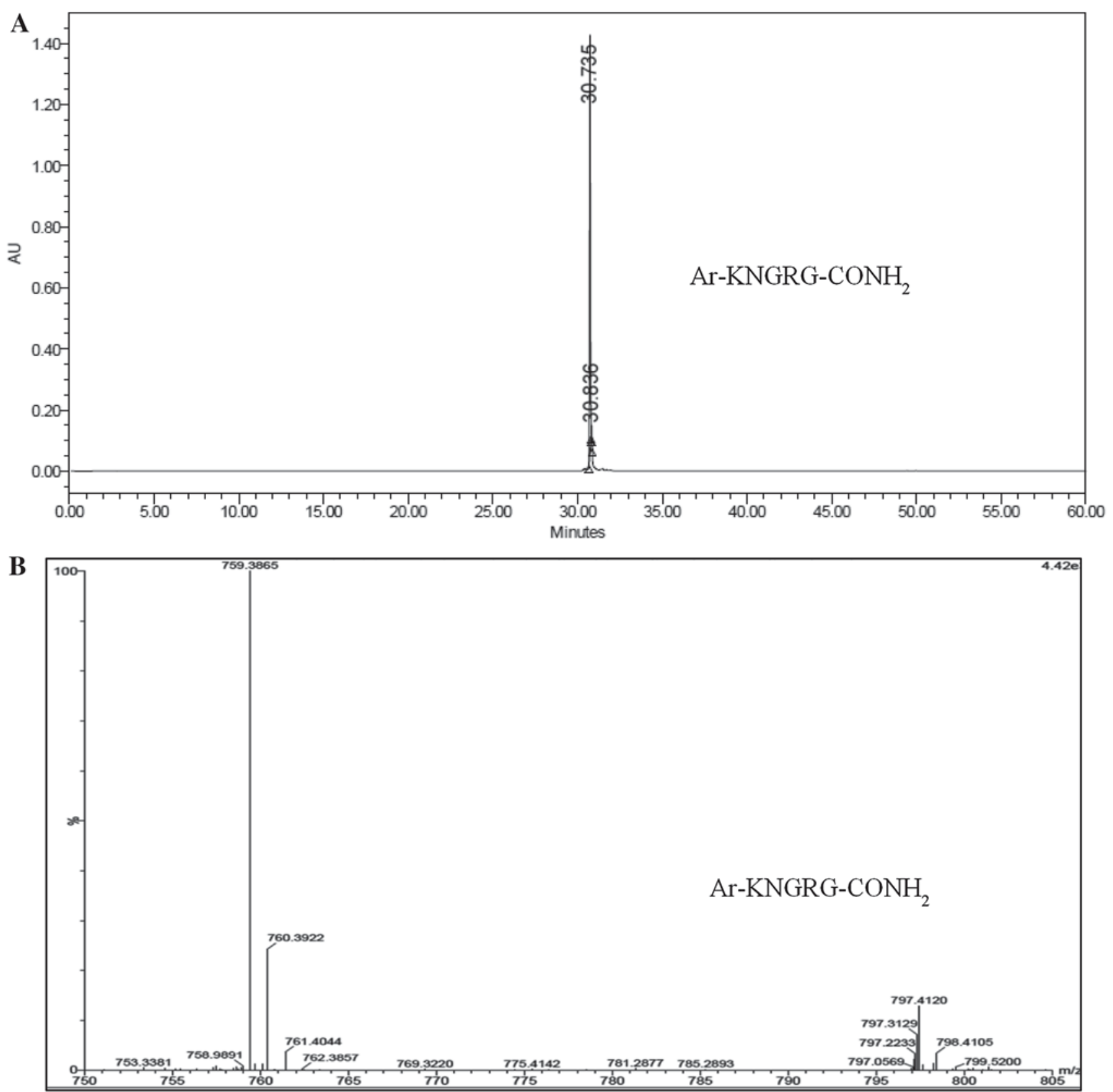

Figure 4. N-terminal modification of pentapeptide: (A) HPLC profile and (B) ESI-MS profile of crude octapeptide after $\mathrm{N}$-terminal modification. The calculated mass of the peptide is 758.3481 .

permit naked-eye detection of cancer cells. We used Fmoc-chemistry protocols for the synthesis of octapeptide and used 1 for monitoring every coupling step during peptide synthesis. After attaching the last amino acid, the Fmoc-protecting group was removed, and the free amine group of the resin-bound peptide was allowed to react with the saturated solution of $1(2 \times 4 \mathrm{~mL} ; 5$ min each $)$ at room temperature. Finally, the N-terminal modified peptide was cleaved off from the resin using TFA-water (9.8:0.2) at room temperature (Figure 2).

High-performance liquid chromatography was used to assess the homogeneity of the N-terminal modified pentapeptide (Ar-NH-KNGRG-CONH${ }_{2}$ ) and octapeptide (Ar-NH-KKNGRGDA-CONH 2 ). The purity of the crude octapeptide was estimated to be about $85.8 \%$ as shown in Figure 3A). ESI mass spectrometric analysis showed the $\mathrm{m} / \mathrm{z}$ value to be 1072.46 , which matched well with the calculated $\mathrm{m} / \mathrm{z}$ value (1071.93) of the octapeptide (Figure 3B). Similarly, the purity $(97.24 \%)$ and mass $(\mathrm{m} / \mathrm{z}=759.38)$ of the pentapeptide was also confirmed by HPLC and mass spectrometry (Figure 4). These results clearly indicated the N-terminal modification the peptides, presumably through oxidative substitution by amine group. ${ }^{21}$ The 


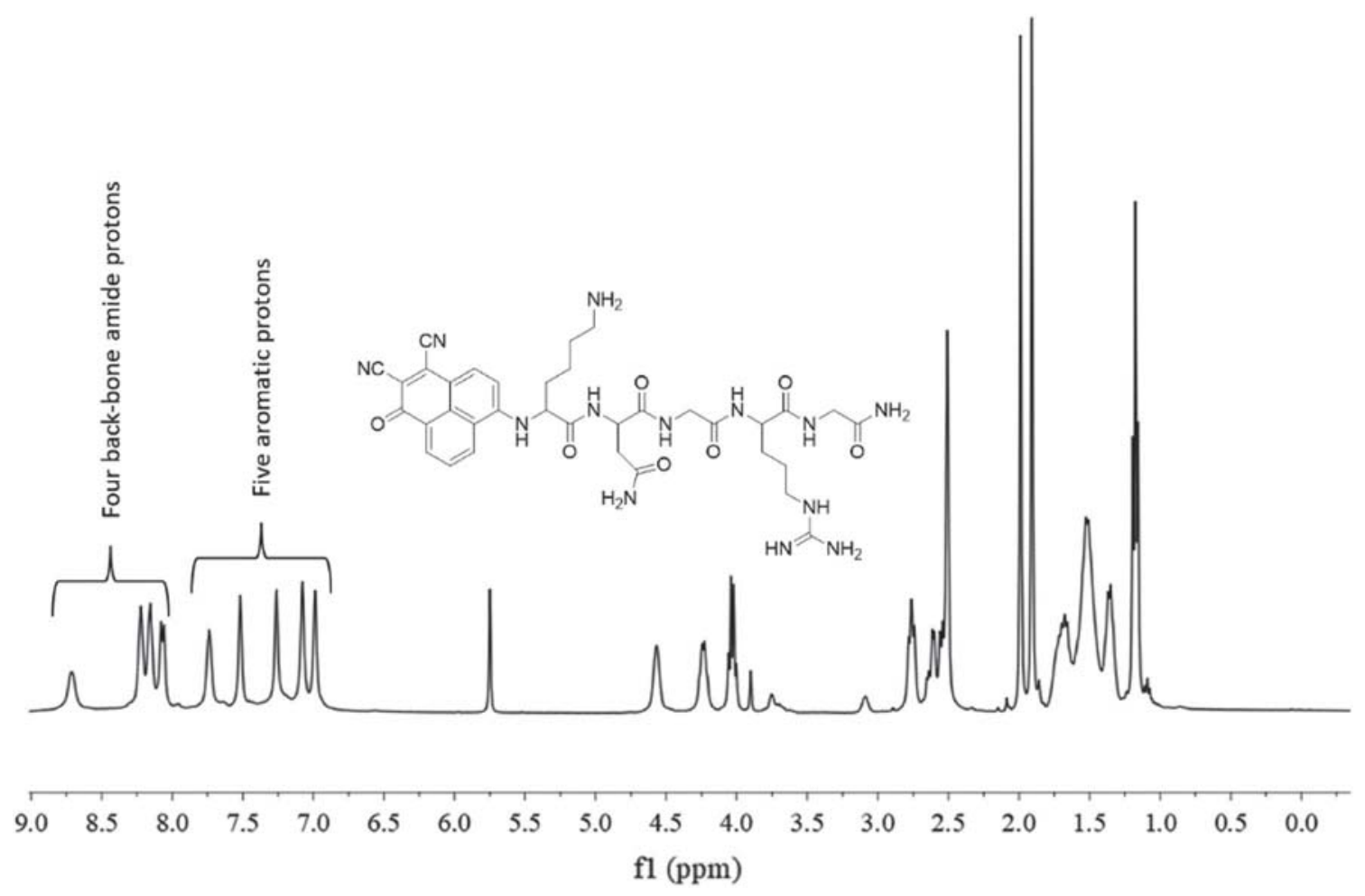

Figure 5. N-terminal modification of pentapeptide: ${ }^{1} \mathrm{H}-\mathrm{NMR}$ (Bruker Avance $400 \mathrm{MHz}$, DMSO-d 6 ) spectrum shows five aromatic proton resonances and four amide proton resonances.

$\mathrm{N}$-terminal labelling was confirmed by ${ }^{1} \mathrm{H}-\mathrm{NMR}$ spectrum of the pentapeptide (Figure 5). Oxidative substitution by amine group takes place due to $\mathrm{C}-\mathrm{H}$ bond activation, which is maximum at the position indicated in Scheme 1. ${ }^{21}$ As seen in Figure 5, only four amide proton resonances and five aromatic proton resonances are observed in the ${ }^{1} \mathrm{H}-\mathrm{NMR}$ spectrum. Thus, ${ }^{1} \mathrm{H}-\mathrm{NMR}$ confirms the formation of only one peptide derivative (one of the three possible regioisomers ${ }^{21}$ ). Considering the reaction condition employed during peptide synthesis, it is likely that only one peptide-appended-regioisomer is formed, as shown in Scheme 1.

As a logical extension, the N-terminal modified octapeptide was assayed for selective detection of cancer cells. Figure 6 demonstrates the ability of the octapeptide to bind cancer cells. Clearly, N-terminal modification is useful for cell imaging.

To confirm the suitability of $\mathbf{1}$ for monitoring solidphase peptide synthesis involving Boc-chemistry protocols, a cationic tetrapeptide $\left(\mathrm{NH}_{2}-\mathrm{KRKA}-\mathrm{COOH}\right)$ was synthesized using Wang resin, and the N-terminus of the peptide was modified with $\mathbf{1}$. The DIPEA used for neutralization after deprotection of Boc-group by TFA, provided the basic medium required for oxidative substitution by amine group. The $\mathrm{N}$-terminus modified tetrapeptide was purified on a HPLC system

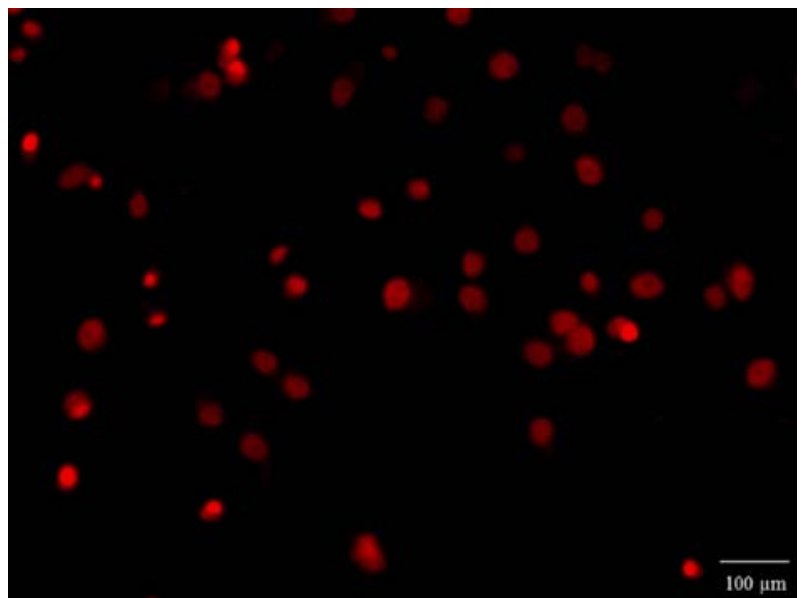

Figure 6. Octapeptide binding to A431 cells: (A) phasecontrast and (B) fluorescent microscopic images.

using a PepRPC reversed-phase column, and a linear gradient consisting of $0.1 \%(\mathrm{v} / \mathrm{v})$ TFA in water and $0.1 \%(\mathrm{v} / \mathrm{v})$ TFA in acetonitrile. The HPLC retention time revealed that the tetrapeptide was hydrophobic (Figure 7A). The calculated mass $(\mathrm{m} / \mathrm{z}=729.00)$ of the tetrapeptide (Ar-NH-KRKA-COOH) was confirmed by MALDI mass analysis $(\mathrm{m} / \mathrm{z}=730.384$, Figure 7B). Since the tetrapeptide was hydrophobic and contained three cationic amino acids, we explored its potential to bind negatively charged bacterial cell 

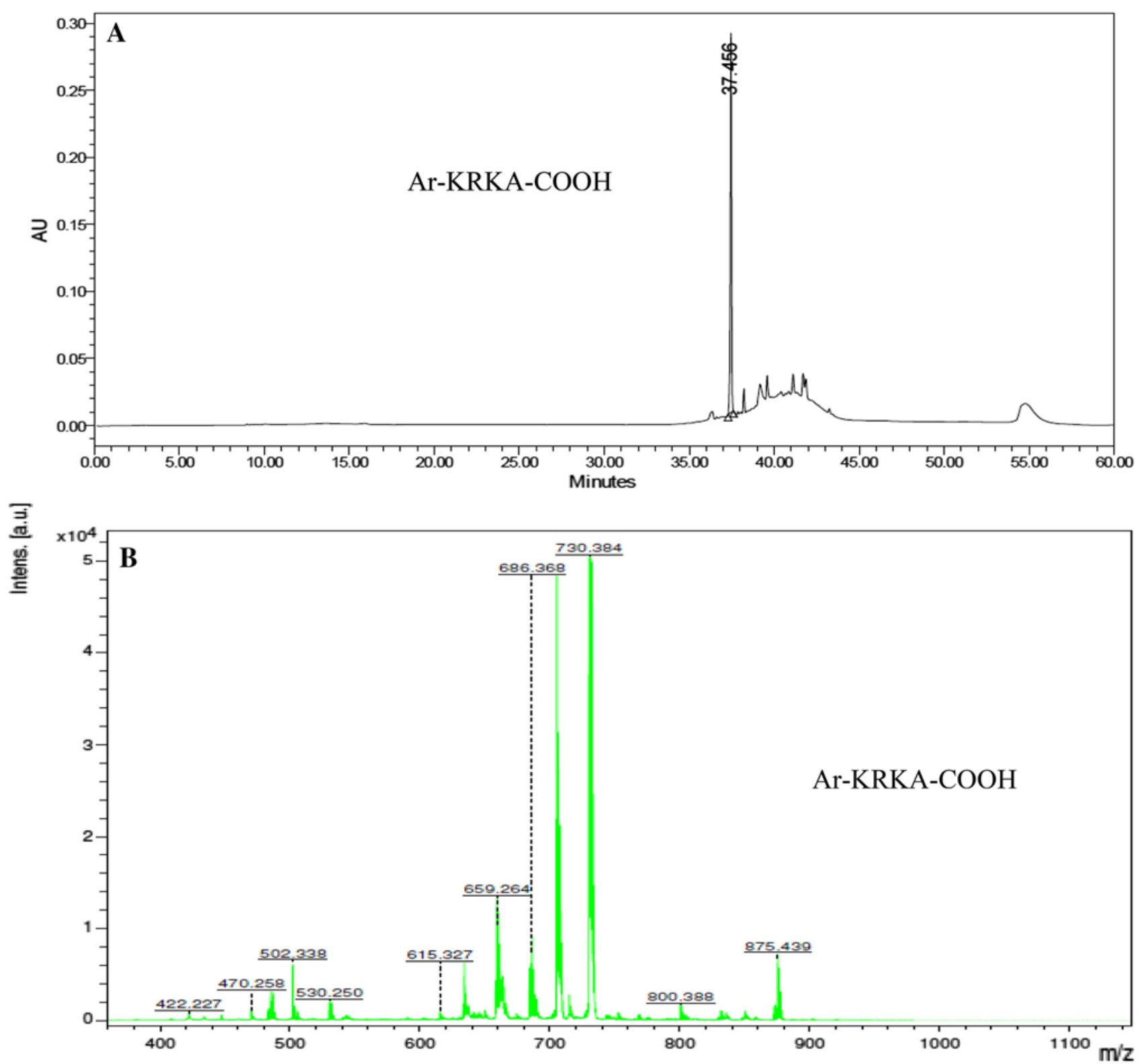

Figure 7. N-terminal modified tetrapeptide: (A) HPLC profile and (B) ESI-MS profile of crude tetrapeptide after N-terminal modification. The calculated mass of the peptide is 729.130 .

membrane. As shown in (Figure 8), the tetrapeptide was useful to identify bacteria owing to the ability of the cationic tetrapeptide to bind negatively charged bacterial cell membrane.

\section{Conclusions}

A general method for naked-eye detection of free amine group during peptide synthesis and for N-terminal modification of resin-bound peptides is reported. Two structurally related compounds $\mathbf{1}$ and $\mathbf{2}$ develop reddish-brown color upon reaction with free amine groups present in growing peptide chains on solid support. The reaction is fast, cost-effective, and it does not require heating. This method is advantageous in the stepwise synthesis of peptides as it allows the detection of free amino group when the coupling is incomplete, prompting the need for a second coupling reaction. The suitability of $\mathbf{1}$ to monitor solid-phase peptide synthesis involving both Fmoc- and Bocchemistry protocols is demonstrated. The utility of $\mathbf{1}$ as a reagent for $\mathrm{N}$-terminal labelling of synthetic peptides is also demonstrated. Further, two short peptide sequences suitable for imaging bacterial and cancer cells are reported. 

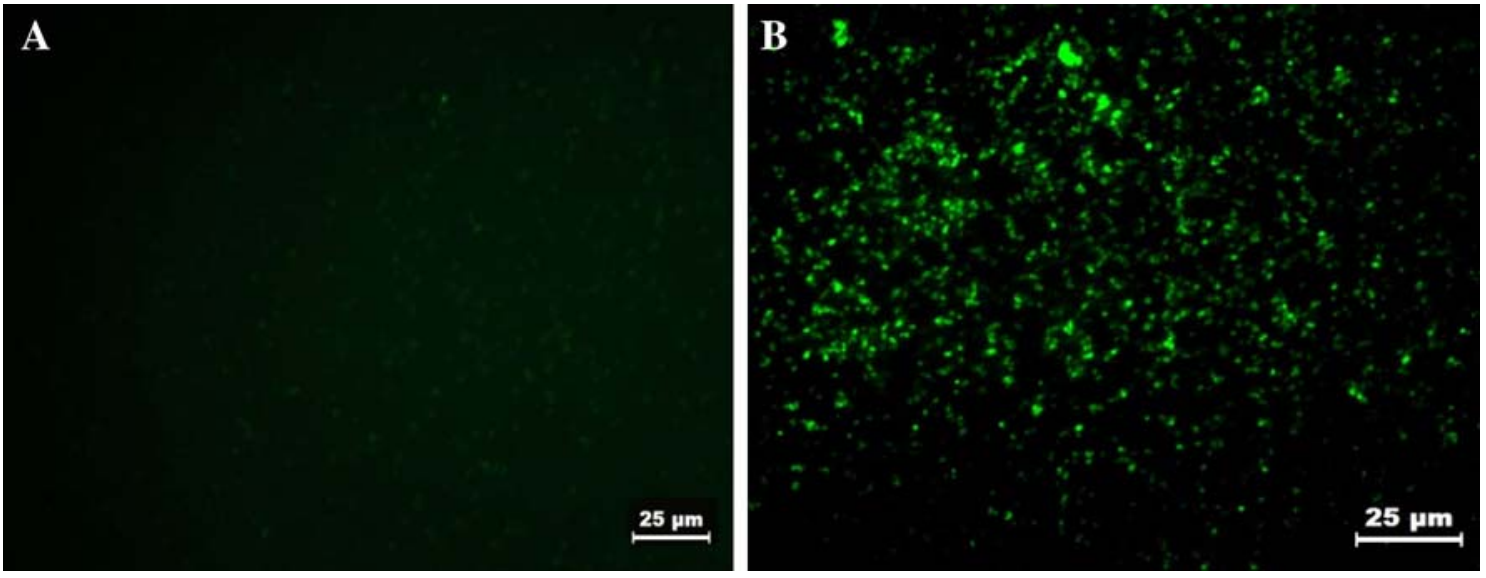

Figure 8. Fluorescent microscopic images of Staphylococus aureus: (A) untreated bacterial cells, and (B) cells treated with $10 \mu \mathrm{g}$ of peptide Ar-KRKA-COOH.

\section{Acknowledgements}

We thank Ms. I Janani for help in octapeptide binding to A431 cells. This work was carried out as part of the PhD program registered at the University of Madras, using a grant BSC0201 from Council of Scientific and Industrial Research, New Delhi.

\section{References}

1. Toy P H and Lam Y 2012 Solid-Phase Organic Synthesis: Concepts, Strategies, and Applications (Hoboken, NJ: Wiley)

2. Atherton E and Sheppard R C 1989 Solid Phase Peptide Synthesis: A Practical Approach (London and New York: Oxford University Press)

3. Chan W C and White P D 2000 Fmoc Solid Phase Peptide Synthesis: A Practical Approach (New York: Oxford University Press)

4. Kaiser E, Colescot R L, Bossinge C D and Cook P I 1970 Color test for detection of free terminal amino groups in solid-phase synthesis of peptides Anal. Biochem. 34595

5. Sarin V K, Kent S B, Tam J P and Merrifield R B 1981 Quantitative monitoring of solid-phase peptide synthesis by the ninhydrin reaction Anal. Biochem. 117 147

6. Hodges R S and Merrifield R B 1975 Monitoring of solid phase peptide synthesis by an automated spectrophotometric picrate method Anal. Biochem. 65241

7. Salisbury S A, Tremeer E J, John W, Davies A, David E I and Owen A 1990 Acylation monitoring in solid phase peptide synthesis by the equilibrium distribution of colored ions J. Chem. Soc. Chem. Commun. 538

8. Hancock W S and Battersby J E 1976 A new micro-test for the detection of incomplete coupling reactions in solid-phase peptide synthesis using 2, 4, 6-trinitrobenzene-sulphonic acid Anal. Biochem. 71260

9. Gisin B F 1972 The monitoring of reactions in solidphase peptide synthesis with picric acid Anal. Chim. Acta $\mathbf{5 8} 248$
10. Brunfeldt K and Christensen T 1972 Process monitoring in solid phase peptide synthesis, amino group blocking effect of impure methylene chloride FEES Lett. 19345

11. Brunfeldt K and Halstrem J 1970 Tritylation of a partially protected pentapeptide synthesized by the Merrifield solid phase method Acta Chem. Scand. 243013

12. Brunfeldt K, Roepstorff P and Thomson J 1969 Process control in automated peptide synthesis In Peptides 1969 E Scoffone (Ed.) p. 148 (North Holland, Amsterdam: Elsevier)

13. Brunfeldt K, Christensen T and Villemoes P 1972 Automatic monitoring of solid phase synthesis of a decapeptide FEBS Lett. 22238

14. Lee Y P and Takahashi T 1966 An improved colorimetric determination of amino acids with the use of ninhydrin Anal. Biochem. 1471

15. Merrifield R B 1963 Solid phase peptide synthesis I: the synthesis of a tetrapeptide J. Am. Chem. Soc. 85 2149

16. Merrifield R B 1964 Solid-phase peptide synthesis III: an improved synthesis of bradykinin Biochemistry 3 1385

17. Peptide Synthesis Protocols 1995 In: Methods in Molecular Biology (Book Series) Vol. 35 Michael W Pennington and Ben M Dunn (Eds.) (Totowa, NJ: Humana Press Inc.)

18. Jullian M, Hernandez A, Maurras A, Puget K, Amblard M, Martinez J and Subra G 2009 N-terminus FITC labeling of peptides on solid support: the truth behind the spacer Tetrahedron Lett. 50260

19. Walker J M 1984 The dansyl method for identifying N-terminal amino acids Methods Mol. Biol. 1203

20. Birtalan E, Rudat B, Kölmel D K, Fritz D, Vollrath S B L, Schepers U and Braise S 2011 Investigating rhodamine B-labeled peptoids: scopes and limitations of its applications Biopolymers 96694

21. Lenk R, Tessier A, Lefranc P, Silvestre V, Planchat A, Blot V, Dubreuil D and Lebreton J 2014 1-Oxo-1H-phenalene2,3-dicarbonitrile heteroaromatic scaffold: revised structure and mechanistic studies J. Org. Chem. 799754 